RESEARCH PAPER

\title{
Influence of livestock systems with live fences of Gliricidia sepium on several soil properties in Tabasco, Mexico
}

\author{
Gilberto Villanueva-López ${ }^{1}$, Pablo Martínez-Zurimendi1,2, Luis Ramírez- \\ Avilés ${ }^{3}$, Fernando Casanova-Lugo ${ }^{4}$, and Aarón Jarquín-Sánchez ${ }^{1}$ \\ ${ }^{1}$ El Colegio de la Frontera Sur. Carretera a Reforma km $15.5 \mathrm{~s} / \mathrm{n}$ Ra. Guineo 2a sección CP. 86280. \\ Villahermosa, Tabasco, Mexico. \\ ${ }^{2}$ Instituto Universitario de Investigación en Gestión Forestal Sostenible. Universidad de Valladolid - \\ Instituto Nacional Investigaciones Agrarias. Avda. Madrid s/n, 34004, Palencia, Spain. \\ ${ }^{3}$ Campus de Ciencias Biológicas y Agropecuarias, Universidad Autónoma de Yucatán. Carretera Mérida \\ Xmatkuil km 15.5 Aptdo. 116 Itzimná. Mérida, Yucatán, Mexico. \\ ${ }^{4}$ Instituto Tecnológico de la Zona Maya, Carretera Chetumal-Escárcega km 21.5, C.P. 77965, Ejido Juan \\ Sarabia, Quintana Roo, Mexico.
}

\begin{abstract}
G. Villanueva-López, P. Martínez-Zurimendi, L. Ramírez-Avilés, F. Casanova-Lugo, and A. Jarquín-Sánchez. 2014. Influence of livestock systems with live fences of Gliricidia sepium on several soil properties in Tabasco, Mexico. Cien Inv. Agr. 41(2): 175-186. The aim of the current study was to evaluate the effects of two livestock systems, a livestock system with live fences (LSLF) of Gliricidia sepium associated with signal grass (Brachiaria decumbens) and a livestock system based on a grass monoculture (LSPM), on specific physical and chemical soil characteristics at different depths and distances from the fence. In each system, we randomly selected 9 plots of $600 \mathrm{~m}^{2}$. A completely randomized design was used with a $2 \times 3$ factorial arrangement in which we analyzed the influence of the livestock systems (LSLF and LSPM), soil strata (0-10, 10-20 and 20$30 \mathrm{~cm}$ ) and the interaction of both factors using a multivariate analysis of variance. In addition, we performed analysis of variance to determine the effect of distance sampling in the LSLF (0-3, 3-6 and 6-9 m). The LSLFs were associated with higher $(\mathrm{P} \leq 0.05)$ soil organic matter $(\mathrm{OM})$, carbon $(\mathrm{C})$ and nitrogen $(\mathrm{N})$ content as well as lower $\mathrm{pH}$ and bulk density (BD) when compared with the LSPM. In both livestock systems, the soil OM, $\mathrm{C}$ and $\mathrm{N}$ were higher $(\mathrm{P} \leq 0.05)$ in the upper $(0-10 \mathrm{~cm})$ strata and in the LSLF at a 3 to $6 \mathrm{~m}$ distance from the live fences. In the LSLF soil, the $\mathrm{pH}$ and BD were similar $(\mathrm{P}>0.05)$ at different depths and distances from the live fences. However, the soil $\mathrm{pH}$ varied between soil depths in the LSPM. Regarding the physical soil properties, only the sand and clay content varied $(\mathrm{P} \leq 0.05)$ at different depths in both systems but not at different distances from the LSLF. We concluded that the LSLF presents high potential to substantially improve the physical and chemical soil properties and provide an important option for reducing soil degradation in future in livestock production systems based on pasture monoculture.
\end{abstract}

Key words: Soil improvement, silvopastoral system, signal grass monoculture, humid tropic.

\section{Introduction}

Past research has demonstrated that grazing animals substantially alter the physical and chemical

Received June 27, 2013. Accepted April 8, 2014 Corresponding author: gvillanueva@ecosur.mx properties of the soil, accelerate erosion, promote compaction, reduce the volume of pore space, influence the velocity decrease of water flow and modify the balance of nutrients. Grazing animals also reduce the organic matter content, promote diversity loss and decrease the soil fertility ( $\mathrm{La}$ Scala et al., 2012). Due to these effects, over the 
past several decades, there has been growing interest in the role of trees and the ecological services they can provide, both above and below ground, in livestock landscapes (Graham et al., 2004). It has been reported that trees are capable of modifying the physical and chemical characteristic of soils. When plant structures (roots, stems, leaves and tree trunks) die and fall to the ground, they enter the humidification process of decomposition, whereby over time, organic matter content, cation exchange capacity and the availability of N, P and K all increase to help curtail land degradation (Manning et al., 2006).

In the state of Tabasco, Mexico, live fences in livestock systems (LSLF) are the most common form of tree cover along rural landscapes, particularly in regions where many tropical forests have been cleared to make way for livestock pastures. The use of live fences is the most popular strategy for introducing trees to livestock systems and is mainly used to define cattle ranch boundaries, divide pastures and define paths that cross fields.

Maldonado et al. (2008) stated that the LSLF includes more than 100 species of trees, with cocoíte (Gliricidia sepium (Jacq.) Kunth ex Walp., palo mulato (Bursera simaruba L. Sarg.) and mote (Erythryna americana Mil.) among the most important species. The LSLF also consists of timber species, such as cedar (Cedrela odorata L.), macuilís (Tabebuia rosea Bertolt. A. DC.) and ceiba (Ceiba pentandra L. Haertn.), and non-timber species, such as palo tinto (Haematoxylum campechianum L.), coconut (Cocos nucifera L.), zapote de agua (Pachira aquatic Aubl.) and various fruit trees. Of these tree species, G. sepium is the most widely used multipurpose native legume. Farmers prefer this species because of the following factors: it is relatively straightforward to plant and manage, easily forms roots from cuttings, displays rapid initial growth and regrowth after intense pruning, tolerates prolonged drought, provides good quality live fence posts, and provides nutritious fodder supplement for cattle and fruit during pruning. Moreover, when live fences are used instead of dead timber posts, fencing costs are reduced by approximately $50 \%$, and live fences last many years (Carvajal, 2005). Other advantages of the LSLF often not perceived by farmers include the following: 1. G. sepium increases the soil nitrogen $(\mathrm{N})$ content through biological fixation undertaken by microorganisms of the genus Rhizobium (Berninger and Salas, 2003); 2. The LSLF alleviates pasture degradation; 3. The LSLF promotes biodiversity conservation; 4 . The LSLF facilitates natural regeneration of trees; 5. The LSLF increases forest patch connectivity by acting as a biological corridor; and 6. Despite the importance of the LSLF in Tabasco, few studies have considered the role of these systems in improving the soil properties, particularly in livestock systems. Therefore, the aim of this study was to evaluate the effect of the LSLF composed of $G$. sepium trees associated with signal pasture (Brachiaria decumbens Stapf), on several physical and chemical soil characteristics.

\section{Materials and methods}

\section{Study area}

This study was conducted in a mountainous region within the municipality of Tacotalpa, Tabasco, Mexico (Figure 1). This region is much more mountainous and consequently experiences higher rainfall than the rest of the state. It is located in the south of the state, between $17^{\circ} 15^{\prime}$ and $17^{\circ}$ $45^{\prime} \mathrm{N}$ and $90^{\circ} 38^{\prime} 08^{\prime \prime}$ and $93^{\circ} 46^{\prime}$, and is bordered by the municipalities of Centla and Centro to the north, the state of Chiapas to the southwest, and the municipality of Macuspana and the state of Chiapas to the east (INEGI, 2009). The region experiences a hot, wet climate, with high temperatures and rainfall throughout the year (Af (m) w"(i') g, according to the Köppen climatic classification, modified by García, 1988). The mean annual temperature is $25^{\circ} \mathrm{C}$, whereas the monthly mean maximum temperature for June ranges from 43 to $45^{\circ} \mathrm{C}$. The monthly mean minimum temperature for December ranges 


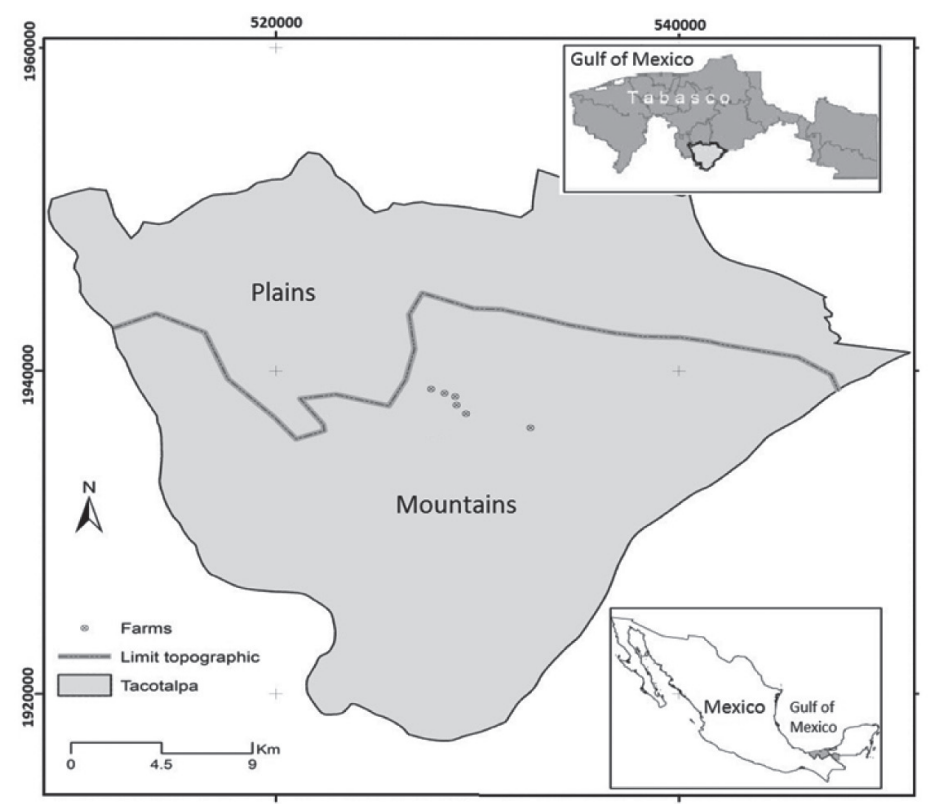

Figure 1. Location of the study area and farms. We installed 3 plots in each farm.

from 18 to $21^{\circ} \mathrm{C}$. The region is characterized by a rainfall average of 3,000 to $4,000 \mathrm{~mm}$ per year. An average monthly high of $569.7 \mathrm{~mm}$ was recorded in September and an average monthly low of $167.4 \mathrm{~mm}$ was recorded in April (INEGI, 2009). The total mean annual evapotranspiration was $1,088.3 \mathrm{~mm}$; the total precipitation recorded during the experimental period (six months) was $1809 \mathrm{~mm}$, and the relative humidity was $66 \%$ (weather information from the station of Tapijulapa, Tacotalpa, Tabasco).

\section{Characteristics of the sampling sites}

Two land use systems were evaluated: 1. Livestock systems with live fences composed of $95 \% G$. sepium trees in association with $B$. decumbens (signal grass) and; 2 . Livestock systems based on a monoculture of signal grass (LSPM). In this study, live fences in the livestock systems are oriented east-west and are used to demarcate farm boundaries, to divide larger pastures, and to provide food and shade to animals. Live fences are pruned every two years, either between November and March or July and August, to obtain posts to repair and establish new fences. A proportion of the wood is used as firewood; the remaining material is left on the ground in the pastures. Table 1 summarizes the main characteristics of the evaluated livestock systems.

\section{Sampling design and plot distribution}

Three farms were selected for each of the livestock production systems. In each farm, a fence was selected from which three plots were randomly allocated. In both livestock systems, plots measured $600 \mathrm{~m}^{2}(30 \times 20 \mathrm{~m})$. In the LSLF, the plots covered both sides of the fence; three sampling areas were located on each side as follows: 1 . Beneath the tree canopy ( 0 to $3 \mathrm{~m}$ from the fence); 2 . On the canopy border and outside the canopy border (3 to $6 \mathrm{~m}$ from the fence) and; 3 . Outside the tree canopy (6 to $9 \mathrm{~m}$ from the fence) (Figure 2). In the case of the LSPM, as most of the ranches are located in the front section abutting the road, the plots only covered the interior part of the farm. As in the LSLF (Figure 2), three sampling areas were used. In each sampling area of both systems, three $3 \times 3 \mathrm{~m}$ sub-plots were randomly allocated at $1.5,4.5$ and $7.5 \mathrm{~m}$ from the 
Table 1. Average values of the general characteristics of the systems evaluated in the Sierra of Tacotalpa, Tabasco, Mexico.

\begin{tabular}{|c|c|c|}
\hline Characteristics & $\begin{array}{c}\text { Livestock systems with } \\
\text { live fences }\end{array}$ & $\begin{array}{l}\text { Livestock systems in } \\
\text { monoculture pasture }\end{array}$ \\
\hline Fences & Gliricidia sepium trees & Poles dead \\
\hline $\begin{array}{l}\text { Trees (or poles) linear } \\
\text { density of approximately } \\
100 \mathrm{~m}\end{array}$ & 111 & (67) \\
\hline Age of system & 31 & 31 \\
\hline Altitude (m a.s.1.) & 50 & 50 \\
\hline Topography & Flat & Flat \\
\hline Objectives of production & $\begin{array}{l}\text { Fattening and } \\
\text { breeding stock }\end{array}$ & $\begin{array}{l}\text { Fattening, } \\
\text { breeding stock and } \\
\text { production milk }\end{array}$ \\
\hline Breeds of cattle & Cebu-Swiss & Cebu-Swiss \\
\hline Average area (ha) & 7.1 & 6.3 \\
\hline Average herd size & 31.6 & 40.0 \\
\hline $\begin{array}{l}\text { Range of stocking rate } \\
\left(\mathrm{AU} \mathrm{ha}^{-1}\right)\end{array}$ & 1 a 5 & 1 a 5 \\
\hline Type of grass & $\begin{array}{l}\text { Brachiaria } \\
\text { decumbens }\end{array}$ & $\begin{array}{l}\text { Brachiaria } \\
\text { decumbens }\end{array}$ \\
\hline Grazing system & Rotational & Rotational \\
\hline Days of grazing & Continuous & Continuous \\
\hline Level of technical & Regular & Good $^{1}$ \\
\hline Technical assistance & Scarce & Scarce \\
\hline
\end{tabular}

${ }^{1}$ Best herd health management (i.e. vaccination and deworming), artificial insemination and growth implants for beef cattle (Grande et al., 2010). AU= animal unit per hectare.

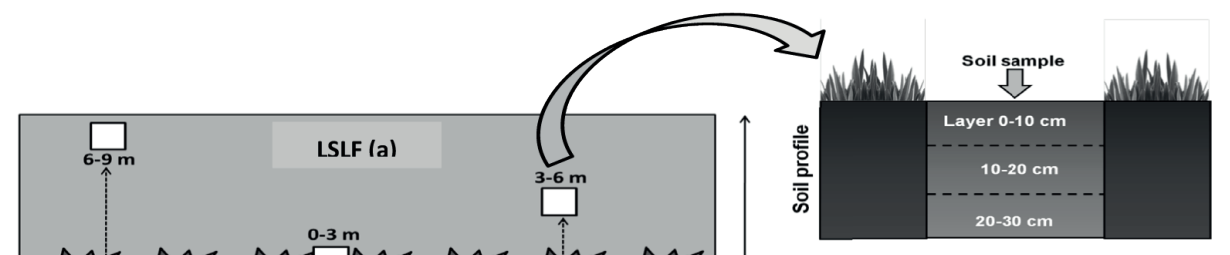

$20.0 \mathrm{~m}$

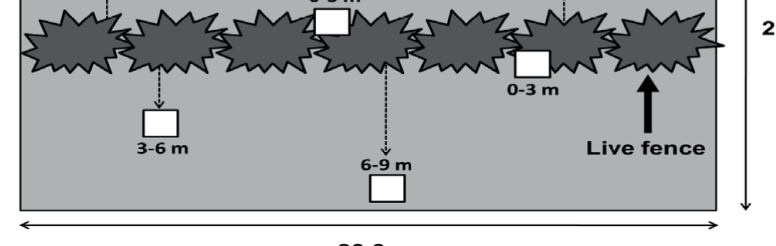

$30.0 \mathrm{~m}$

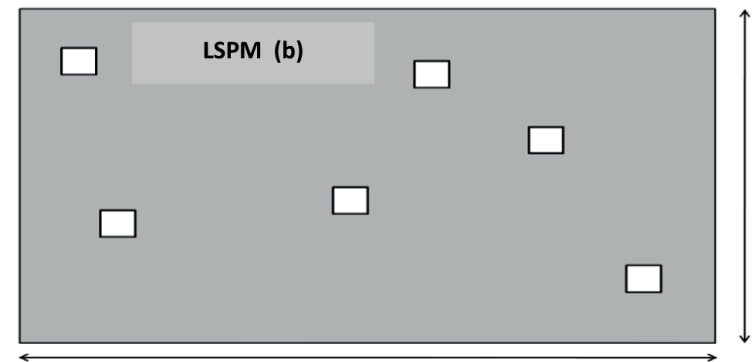

Figure 2. Plot design, sampling areas and sites in the LSLF (a) and LSPM (b). 
fence, respectively. All plots were fenced 30 days before the start of the experiment (December 2011) and at the end of the experiment (December 2012) to prevent damage by cattle.

\section{Soil sampling and analysis}

Soil samples were collected in the sampling areas within each sub-plot and land use system. In total, $30 \times 30 \times 30 \mathrm{~cm}$ pits were dug within each sub-plot; soil samples were obtained at different strata within the sub-plots $(0-10,10-20$ and $20-30 \mathrm{~cm})$ and kept in plastic containers. In each sub-plot, samples from the same soil stratum were pooled. The soil was mixed until reaching a uniform color, followed by removal of a $500 \mathrm{~g}$ sub-sample that was placed into tagged plastic bags. All pooled samples were dried in the shade at room temperature before being ground a to 2-mm particle size. The dry combustion method was used to determine the organic matter $(\mathrm{OM})$ content; soil $\mathrm{pH}$ was determined using a 1:1 relationship with water, and nitrogen $(\mathrm{N})$ content was determined using the normal Kjeldahl method (Sparks et al., 2007). The texture was determined using a hydrometer method, and the bulk density (BD) was estimated by collecting a known volume of soil using a metal ring pressed into the soil (intact core), and determining the weight after drying (McKenzie et al., 2004); to estimate the $\mathrm{C}$ content in the $\mathrm{OM}$, the factor 1.72 was used (Campbell et al., 2010).

\section{Statistical analysis}

A completely randomized design was used with a $2 \times 3 \times 3$ factorial arrangement. We analyzed the influence of the livestock systems (LSLF and LSPM), soil strata $(0-10,10-20$ and $20-30 \mathrm{~cm})$ and the interaction of both factors using a multivariate analysis of variance. In addition, we performed analysis of variance to determine the effect of distance sampling in the LSLF (0-3, 3-6 and 6-9 m). The measured soil variables were as follows: $\mathrm{pH}, \mathrm{BD}$, contents of $\mathrm{C}$, $\mathrm{OM}$ and $\mathrm{N}$, and texture. The statistical analysis was performed using the software Statistica version 8.0 for Windows (StatSoft, Inc. Tulsa, Oklahoma, USA). To test for significant differences in the means, we used Tukey's test at $95 \%$ probability.

\section{Results}

The results of the multivariate analysis show that there was a significant effect of the system and soil sampling depth. The soil $\mathrm{pH}$ and bulk density (7.5 and 1.5, respectively) were higher $(\mathrm{F}=46.9$, $\mathrm{P} \leq 0.01 ; \mathrm{F}=191.75, \mathrm{P} \leq 0.01)$ in the LSPM than in the LSLF (7.2 and 1.3, respectively). However, the soil silt content was $5 \%$ higher $(\mathrm{F}=16.812$, $\mathrm{P} \leq 0.01$ ) in the LSLF (Figure 3) than in the soil of the LSPM. The sand and clay proportions, OM, $\mathrm{C}$, and $\mathrm{N}$ contents were similar between systems ( $P>0.05$; Figure 3 ). In addition, the effect of the interaction between systems and soil sampling depth was not significant $(\mathrm{F}=1.25, \mathrm{P}>0.245)$.

When the effect of depth in the two livestock systems was analyzed, we found that the LSLF resulted in greater $(\mathrm{F}=2.97 ; \mathrm{P} \leq 0.05)$ concentrations of $\mathrm{OM}, \mathrm{C}$ and $\mathrm{N}$ in the upper strata $(0-10$ $\mathrm{cm})$ than in the remaining strata $(20-30 \mathrm{~cm}$ and $10-20 \mathrm{~cm})$. The proportion of sand was greater in the upper strata $(\mathrm{F}=16.42 ; \mathrm{P} \leq 0.01)$, whereas the bottom strata $(20-30 \mathrm{~cm})$ displayed the highest proportion of clay $(\mathrm{F}=9.79 ; \mathrm{P} \leq 0.01)$. At different soil depths, the proportion of silt, soil bulk density and $\mathrm{pH}$ were similar ( $\mathrm{P}>0.05$; Table 2$)$. The LSPM resulted in a lower $(\mathrm{F}=2.8 ; \mathrm{P} \leq 0.06)$ $\mathrm{pH}$ and a higher $(\mathrm{F}=3.44 ; \mathrm{P} \leq 0.03)$ concentration of $\mathrm{OM}$ in the upper strata $(0-10 \mathrm{~cm})$. However, the strata depths of $10-20 \mathrm{~cm}$ and $20-30 \mathrm{~cm}$ presented the highest proportions of clay $(\mathrm{F}=7.99 ; \mathrm{P} \leq 0.04)$. The soil bulk density, $\mathrm{C}$ and $\mathrm{N}$ contents and soil silt proportions were similar among soil strata ( $\mathrm{P}>0.05$; Table 2).

Moreover, when the effect of sampling distance in the LSLF was analyzed, we found that the OM, $\mathrm{C}$ and $\mathrm{N}$ contents were greater $(\mathrm{F}=3.51 ; \mathrm{P} \leq 0.03)$ at a distance of 3-6 $\mathrm{m}$ from the live fences than 
Table 2. Soil properties at different strata depths $(0-10 \mathrm{~cm}, 10-20 \mathrm{~cm}$ and 20-30 $\mathrm{cm})$ in livestock systems with live fences of G. sepium and in livestock systems in pasture monoculture in Tacotalpa, Tabasco, Mexico.

\begin{tabular}{|c|c|c|c|c|c|c|}
\hline \multirow[b]{3}{*}{ Parameters } & \multicolumn{6}{|c|}{ Soil strata } \\
\hline & \multicolumn{3}{|c|}{ Livestock systems with live fences } & \multicolumn{3}{|c|}{ Livestock systems in pasture monoculture } \\
\hline & $0-10 \mathrm{~cm}$ & $10-20 \mathrm{~cm}$ & $20-30 \mathrm{~cm}$ & $0-10 \mathrm{~cm}$ & $10-20 \mathrm{~cm}$ & $20-30 \mathrm{~cm}$ \\
\hline $\mathrm{pH}$ & $7.2 \pm 0.06 \mathrm{a}$ & $7.2 \pm 0.05 \mathrm{a}$ & $7.3 \pm 0.05 \mathrm{a}$ & $7.5 \pm 0.06 \mathrm{a}$ & $7.6 \pm 0.05 b$ & $7.6 \pm 0.07 b$ \\
\hline $\mathrm{BD}\left(\mathrm{g} \mathrm{cm}^{-3}\right)$ & $1.3 \pm 0.03 \mathrm{a}$ & $1.3 \pm 0.03 \mathrm{a}$ & $1.3 \pm 0.03 \mathrm{a}$ & $1.5 \pm 0.05 \mathrm{a}$ & $1.5 \pm 0.02 \mathrm{a}$ & $1.5 \pm 0.02 \mathrm{a}$ \\
\hline $\mathrm{OM}(\%)$ & $5.7 \pm 0.54 \mathrm{a}$ & $4.1 \pm 0.47 \mathrm{~b}$ & $4.6 \pm 0.50 \mathrm{~b}$ & $4.9 \pm 0.05 b$ & $4.4 \pm 0.37 b$ & $3.9 \pm 0.42 b$ \\
\hline $\mathrm{C}(\%)$ & $3.3 \pm 0.31 \mathrm{a}$ & $2.4 \pm 0.27 \mathrm{~b}$ & $2.7 \pm 0.29 \mathrm{~b}$ & $2.9 \pm 0.29 \mathrm{a}$ & $2.6 \pm 0.21 \mathrm{a}$ & $2.3 \pm 0.24 \mathrm{a}$ \\
\hline $\mathrm{N}(\%)$ & $0.29 \pm 0.03 \mathrm{a}$ & $0.20 \pm 0.02 b$ & $0.23 \pm 0.02 b$ & $0.25 \pm 0.03 \mathrm{a}$ & $0.22 \pm 0.02 \mathrm{a}$ & $0.19 \pm 0.02 \mathrm{a}$ \\
\hline Sand $(50-1000 \mu \mathrm{m}, \%)$ & $30.0 \pm 0.98 \mathrm{a}$ & $25.0 \pm 1.04 \mathrm{~b}$ & $20.0 \pm 1.34 \mathrm{c}$ & $30 \pm 2.36 \mathrm{a}$ & $26 \pm 1.23 \mathrm{~b}$ & $25 \pm 1.34 \mathrm{~b}$ \\
\hline Silt $(2-50 \mu \mathrm{m}, \%)$ & $40.0 \pm 1.25 \mathrm{a}$ & $42.0 \pm 1.02 \mathrm{a}$ & $42.0 \pm 1.47 \mathrm{a}$ & $37 \pm 1.44 \mathrm{a}$ & $37 \pm 1.01 \mathrm{a}$ & $37 \pm 1.20 \mathrm{a}$ \\
\hline Clay $(<2 \mu \mathrm{m}, \%)$ & $30.0 \pm 1.53 \mathrm{c}$ & $33.0 \pm 0.88 \mathrm{~b}$ & $38.0 \pm 1.33 \mathrm{a}$ & $32 \pm 2.06 \mathrm{~b}$ & $37 \pm 2.02 \mathrm{a}$ & $38 \pm 1.92 \mathrm{a}$ \\
\hline
\end{tabular}

Means within rows followed by different letters are significantly different (Tukey's test, $\mathrm{P} \leq 0.05$ ).

at a distance of 0-3 $\mathrm{m}$ and 3-9 $\mathrm{m}$. Furthermore, the $\mathrm{pH}$, soil bulk density and the proportion of sand, silt and clay were not influenced by sampling distance from the live fences (Table 3).

\section{Discussion}

The results show that the LSLF from G. sepium trees improved certain physical and chemical soil characteristics. The soil $\mathrm{pH}$ in these livestock systems was close to neutral (7.2), particularly in the upper strata $(0-10 \mathrm{~cm})$, which favors a better biological system because the conditions of nutrients are favorable without being extreme, and the assimilation of phosphorus is at maximum. The almost neutral soil $\mathrm{pH}$ may be due to a higher content of OM or the initial $\mathrm{N}$ content in the original plant material associated with the formation of $\mathrm{NH}^{+}$, which consumes protons (Wong et al., 2000). It may also be because the OM of the soil has carboxylic and phenolic groups that behave as weak acids and tend to decrease the soil $\mathrm{pH}$ (Martínez et al., 2008). This same author noted that in almost neutral soils or soils that have high amounts of carbonates and bicarbonates, the soil $\mathrm{pH}$ decreases by increasing the partial pressure of $\mathrm{CO}_{2}$ in the soil atmosphere. The $\mathrm{CO}_{2}$ from the atmosphere combines with water and forms carbonic acid, which generates the disassociation of $\mathrm{H}^{+}$and acidifies the soil. A neutral $\mathrm{pH}$ increases the solubility of various nutrients (Martínez et al., 2008), promotes microorganism activity and, consequently, improves soil quality, which has been shown by other authors (Dube et al., 2012) as being essential for adequate grass and tree growth. G. sepium trees in the livestock systems may increase the soil $\mathrm{N}$ content through

Table 3. Soil properties at different sampling distances (0-3 m, 3-6 m and 6-9 m) from the livestock systems with live fences of $G$. sepium in Tacotalpa, Tabasco, Mexico.

\begin{tabular}{lccc}
\hline & \multicolumn{3}{c}{ Sampling distance } \\
\cline { 2 - 4 } Parameters & $0-3 \mathrm{~m}$ & $3-6 \mathrm{~m}$ & $6-9 \mathrm{~m}$ \\
\hline $\mathrm{pH}$ & $7.3 \pm 0.05 \mathrm{a}$ & $7.2 \pm 0.06 \mathrm{a}$ & $7.3 \pm 0.05 \mathrm{a}$ \\
$\mathrm{BD}\left(\mathrm{g} \mathrm{cm}^{-3}\right)$ & $1.3 \pm 0.03 \mathrm{a}$ & $1.3 \pm 0.03 \mathrm{a}$ & $1.3 \pm 0.03 \mathrm{a}$ \\
$\mathrm{OM}(\%)$ & $4.4 \pm 0.40 \mathrm{~b}$ & $5.9 \pm 0.59 \mathrm{a}$ & $4.1 \pm 0.49 \mathrm{~b}$ \\
$\mathrm{C}(\%)$ & $2.6 \pm 0.23 \mathrm{~b}$ & $3.4 \pm 0.35 \mathrm{a}$ & $2.4 \pm 0.29 \mathrm{~b}$ \\
$\mathrm{~N}(\%)$ & $0.2 \pm 0.02 \mathrm{~b}$ & $0.3 \pm 0.03 \mathrm{a}$ & $0.2 \pm 0.02 \mathrm{~b}$ \\
Sand $(50-1000 \mu \mathrm{m}, \%)$ & $25 \pm 1.36 \mathrm{a}$ & $26 \pm 1.50 \mathrm{a}$ & $25 \pm 1.19 \mathrm{a}$ \\
Silt $(2-50 \mu \mathrm{m}, \%)$ & $41 \pm 1.07 \mathrm{a}$ & $42 \pm 1.19 \mathrm{a}$ & $41 \pm 1.50 \mathrm{a}$ \\
Clay $(<2 \mu \mathrm{m}, \%)$ & $34 \pm 1.48 \mathrm{a}$ & $32 \pm 1.30 \mathrm{a}$ & $34 \pm 1.46 \mathrm{a}$ \\
\hline
\end{tabular}

Means within rows followed by different letters are significantly different (Tukey's test, $\mathrm{P} \leq 0.05$ ). 

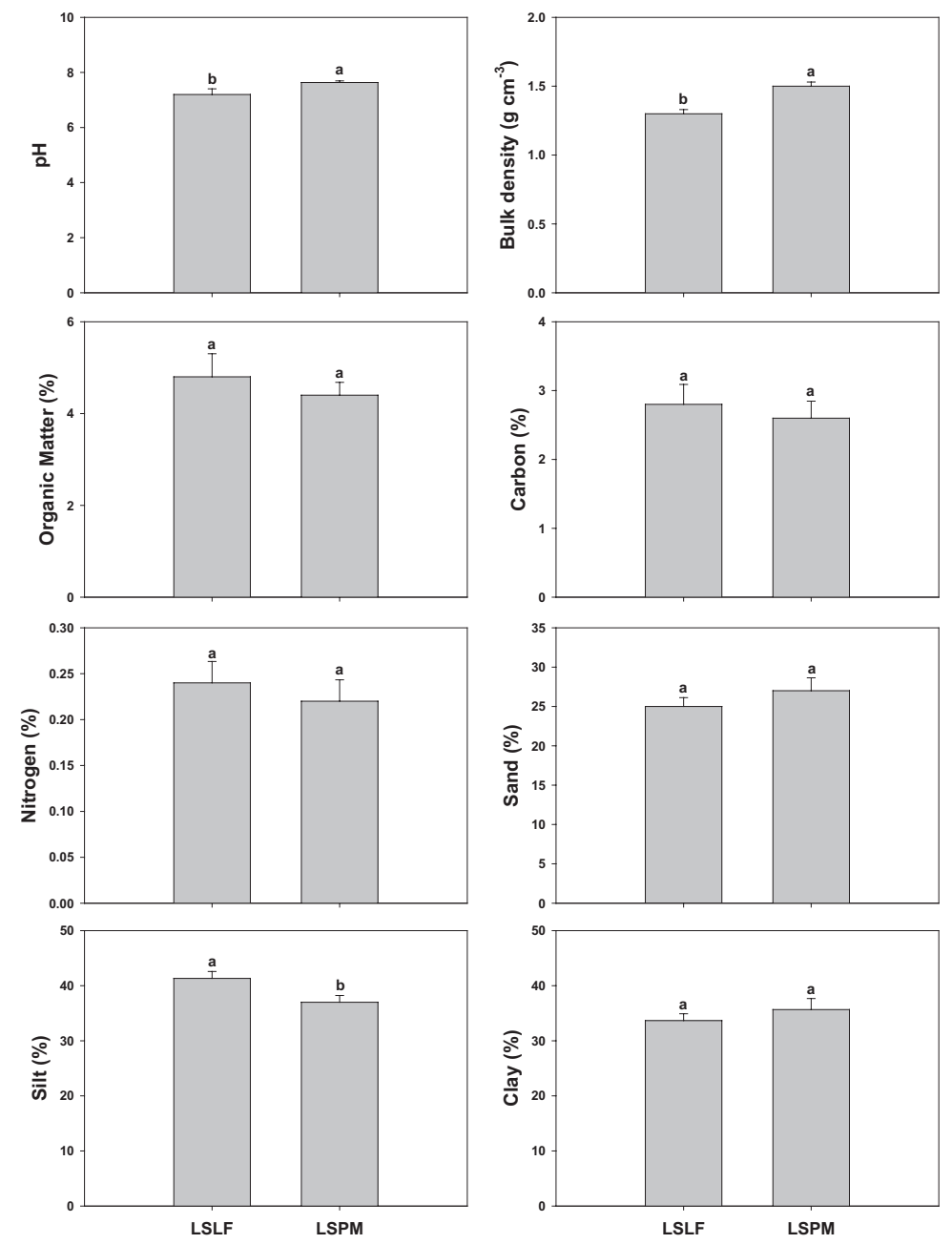

Figure 3. Comparisons between the LSLF and LSPM on soil properties in Tacotalpa, Tabasco, Mexico. Different letters are significantly different according to Tukey's test $(\mathrm{P} \leq 0.05)$.

biological $\mathrm{N}$ fixation performed by Rhizobium bacteria (Berniger and Salas, 2003).

Furthermore, in the LSLF, G. sepium trees use their roots to recover soil nutrients from within deep strata, which is an action that more superficial grass roots are unable to achieve (Schoeneberger, 2008). In addition, high amounts of soil OM were associated with the G. sepium trees in the live fence systems; the tree litter eventually decomposes and releases available plant nutrients into the pasture agro-ecosystems (Graham et al., 2004; Klein et al., 2008). In addition, the shadow generated by the presence of trees in the LSLF G. sepium contributed to lower soil temperatures below the projection of the crown, and the relative humidity and soil moisture was most likely higher than in the soil of the LSPM. These adequate humidity conditions allow nutrients to remain available to plants that can utilize them efficiently for growth. These nutrients eventually return to the soil through cycling, thus promoting optimum physical and chemical soil characteristics (Oelbermann et al., 2006).

By contrast, the soil in the LSPM presented a $\mathrm{pH}$ of 7.5, which shows the importance of trees to 
increase the OM content and yield more neutral $\mathrm{pH}$ levels in pastures. Past studies have shown that soils with a $\mathrm{pH}$ higher than 7.5 could affect soil microorganism activity, and consequently, pasture development, particularly in grass species with radical growth deeper than $10 \mathrm{~cm}$ (Graham et al., 2004). However, in the present study there were differences between the evaluated livestock systems; the $\mathrm{pH}$ was higher than reported by Matos et al. (2012) for a silvopastoral system of apple trees associated with Dactylis glomerata grass. This system presented a $\mathrm{pH}$ of 5 in the upper $0-20 \mathrm{~cm}$ strata compared with a $\mathrm{pH}$ of 6.3 for the same soil strata in a monoculture crop system. This difference suggests that G. sepium trees in the LSLF in the current study are capable of decreasing the soil $\mathrm{pH}$ toward a more neutral $\mathrm{pH}$.

The soil BD at different soil strata and distances from the fence was higher in the LSPM than in the LSLF (Tables 2 and 3). In both systems, the $\mathrm{BD}$ was within the 1.1 to $1.6 \mathrm{~g} \mathrm{~cm}^{-3}$ range, which indicates that both systems have a medium soil texture with low porosity and compaction and favorable physical conditions for plant growth (Sánchez et al., 2003; Pajares et al., 2010). The low values found in the LSLF could be associated with many factors such as poaching (soil damage from heavy livestock feet), higher contents of OM, high soil and air humidity (Matos et al., 2012), the amount, size and distribution of tree roots, as well as the amount of herbaceous roots, which favor soil microorganism development and modify soil texture and soil management (Manning et al., 2006). Carter (2002) reported that maintaining adequate levels of $\mathrm{OM}$ helped to decrease the $\mathrm{BD}$ and resistance to soil compaction. In Guatemala, Schmitt et al. (2012) found a soil $\mathrm{BD}$ range of 0.5 to $1.0 \mathrm{~g} \mathrm{~cm}^{-3}$ and 0.2 to 0.55 $\mathrm{g} \mathrm{cm}^{-3}$ in a coffee agroforestry system and forest ecosystem, respectively. Matos et al. (2012) reported soil $\mathrm{BD}$ values of 1.3 and $1.5 \mathrm{~g} \mathrm{~cm}^{-3}$ for the strata depths of $0-10$ and $10-20 \mathrm{~cm}$, respectively, in a silvopastoral system of apple trees associated with D. glomerata grass and 1.4 and $1.7 \mathrm{~g} \mathrm{~cm}^{-3}$ for the strata depths of $0-10$ and $10-20$ $\mathrm{cm}$, respectively, in a grass monoculture and farmland. Howard and Singer (1981) found that the $\mathrm{BD}$ in forest soils ranged from 0.51 to 1.49 $\mathrm{g} \cdot \mathrm{cm}^{-3}$. Sánchez et al. (2003) reported a BD close

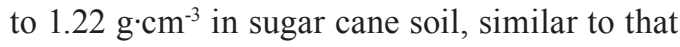

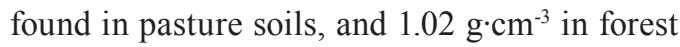
soils. These studies provide sufficient evidence to suggest that trees help reduce soil compaction in a large variety of production systems.

In the LSLF, the OM, $\mathrm{C}$ and $\mathrm{N}$ in different strata and at specific distances from the fence were positively influenced by G. sepium trees that formed the live fences. This study revealed that the highest $\mathrm{OM}, \mathrm{C}$ and $\mathrm{N}$ contents were recorded in the soil upper stratum $(0-10 \mathrm{~cm})$ at a distance of 3-6 $\mathrm{m}$ from the fence; the stratum depths of 20-30 $\mathrm{cm}$ and 0-3 $\mathrm{m}$ from the fence presented intermediate values, whereas the lowest values were recorded in the strata depth of $10-20 \mathrm{~cm}$ at a distance of 6-9 $\mathrm{m}$ from the fence (Tables 2 and 3). This is in agreement with Dube et al. (2012); the authors found $9.8 \%$ and $4.4 \%$ of soil $\mathrm{C}$ content at the $0-5$ and $5-20 \mathrm{~cm}$ soil strata, respectively, in monoculture pastures. The soil OM content has an important role in the development of soil structure as it acts as a attractant for soil particles, thus increasing the soil structure stability by increasing organic-mineral aggregates. In addition, it also improves water infiltration into the soil. A high soil OM content increases the amount of interchange cations that act as a link between clay and OM. In a previous study, the high soil OM content was most likely associated with the high availability of nutrients such as $\mathrm{N}$, soil type, grass physiological stage, as well as the length of the dry and wet seasons (Moya et al., 2010). This suggests that in addition to improving the chemical soil properties, G. sepium trees in livestock systems also improve the physical soil characteristics and, when associated with grasses, possess a high potential to increase the $\mathrm{C}$ and $\mathrm{N}$ content.

Furthermore, G. sepium trees have the potential to increase the $\mathrm{C}$ and $\mathrm{N}$ concentration by 20 to 
$100 \%$ through the action of $\mathrm{N}$ fixing organisms (Schoeneberger, 2008). It is hypothesized that the high $\mathrm{OM}, \mathrm{C}$ and $\mathrm{N}$ content in both the upper $(0-10 \mathrm{~cm})$ soil stratum and at $3-6 \mathrm{~m}$ from the live fences could be associated with the high amount of decomposing litter and woody stems, litter, and dead grass roots, as well as the increased microbial population due to the humidity generated by tree shade. These factors are important for efficient water and nutrient uptake from the upper stratum, which are usually characterized by OM accumulation and relatively large amounts of available nutrients (Tapia et al., 2005). Clay soils have a high capacity to accumulate $\mathrm{C}$ because mineral clay stabilizes and accumulates OM.

Regarding the LSPM, the high OM, C and N soil contents found in upper soil strata $(0-10 \mathrm{~cm})$ were reduced in the lower strata (Table 2). Soto et al. (2010) reported similar findings for different agroforestry systems: traditional milpa with trees, taungya, natural secondary vegetation and enriched secondary vegetation, grasslands pastures with live fences, pastures without trees, and pastures with dispersed trees, in the state of Chiapas, Mexico. The high concentration of nutrients in the upper strata $(0-10 \mathrm{~cm})$ of pasture soils is most likely a result of high root content in this stratum. These roots experience a low rate of decomposition because of their high fiber content; however, they also have a short life cycle that allows the frequent incorporation of dead material into the soil and therefore the formation of a soil profile with a high OM content.

In both livestock systems, soil texture changes were due to differences in the sand and clay proportions in all the strata (Table 2). The highest proportion of sand was found in the upper soil stratum $(0-10$ $\mathrm{cm}$ ), whereas the highest clay content was found in the $20-30 \mathrm{~cm}$ stratum. The high sand content in the upper stratum indicates high porosity in this part of the soil. A combination of high sand and OM content facilitates the movement of air and improves the soil structure and water infiltration, thus helping prevent detrimental soil waterlogging and flooding. Under this scenario, the problems of soil compaction would most likely be minimal or even non-existent throughout the year. Clay is relatively impermeable; therefore, a high proportion of clay found at the bottom stratum, rather than closer to the surface, also helps to hold water, prevent soil waterlogging, increase surface runoff, decrease flooding and protect soil organic matter in pastures (Pajares et al., 2010). Each clay particle has negative electric charges on its outer surface that attract and reversibly bind cations. Many cations such as potassium $\left(\mathrm{K}^{+}\right)$and magnesium $\left(\mathrm{Mg}^{++}\right)$are essential for plant growth and are retained in the clay soil particles. The results recorded in the present study differ from those reported by Matos et al. (2012), who found a higher proportion of sand ( 86.7 vs $81.5 \%$ ) but a lower proportion of silt (3.0 vs 3.9\%) and clay (10.2 vs $14.6 \%)$ in silvopastoral systems, grass monocultures and crop fields, respectively. However, the proportions of silt (44\%) and clay (32\%) are similar to those reported by Moya et al. (2010) in forest systems. It is worth emphasizing that although the proportions of sand, clay and silt in soil from the LSLF were not significantly affected by distance from the fence, the sand and clay proportions were higher at 3-6 $\mathrm{m}$ and the proportion of silt was highest at 0-6 $\mathrm{m}$ from the fence. This suggests that clay content increases with distance from the fence.

The chemical and physical soil properties in live fence livestock systems formed by trees of G. sepium showed a different behavior than in pasture monoculture livestock systems. The $\mathrm{pH}$ in the livestock systems with live fences was closer to neutral, the soil was less dense and there was a greater proportion of silt. Livestock systems with live fences showed significant effects on certain soil chemical and physical properties, both horizontally (30 $\mathrm{cm}$ soil depth) and vertically (up to 6 feet away from the fence). These changes, instigated by livestock systems with live fences, were due to higher OM, C, $\mathrm{N}$ contents, as well as optimal $\mathrm{pH}$ values, soil 
bulk density and sand and clay proportions for pasture and tree development. By contrast, the livestock system in a monoculture pasture of $B$. decumbens was more vulnerable to negative changes in soil characteristics; this was possibly due to trampling and the absence of tree sources of nitrogen-rich organic matter, which could help improve soil fertility and structure.

\section{Acknowledgments}

We thank El Colegio de la Frontera Sur for the facilities provided to M. C. Gilberto Villanueva López for his PhD in Agricultural Sciences at Universidad Autónoma de Yucatán, Mexico. We also thank the Consejo Nacional de Ciencia y Tecnología for the financial support to conduct these studies.

\section{Resumen}

G. Villanueva-López, P. Martínez-Zurimendi, L. Ramírez-Avilés, F. Casanova-Lugo y A. Jarquín-Sánchez. 2014. Influencia de los sistemas ganaderos con cercas vivas de Gliricidia sepium sobre algunas propiedades del suelo en Tabasco, México. Cien Inv. Agr. 41(2): 175-186. El objetivo de este estudio fue evaluar el efecto de dos sistemas ganaderos, un sistema ganadero con cercas vivas (SGCV) de Gliricidia sepium asociado con pasto señal (Brachiaria decumbens), y un sistema ganadero en monocultivo de pasto (SGMP), sobre algunas características físicas y químicas del suelo a diferentes profundidades y distancias de la cerca. En cada sistema se seleccionaron aleatoriamente 9 parcelas de $600 \mathrm{~m}^{2}$. Se utilizó un diseño estadístico completamente al azar con arreglo factorial $2 \times 3$; donde se analizó la influencia de los sistemas ganaderos (SGCV y SGMP), la profundidad de muestreo $(0-10,10-20$ y de 20-30 cm) y la interacción de ambos factores, través de un análisis multivariado de varianza. Además se realizó un análisis de varianza para determinar el efecto de la distancia de muestreo en los SGCV (0-3, 3-6 y 6-9 m). Los SGCV fueron asociados con altos contenidos de materia orgánica (MO), carbón $(\mathrm{C})$ y nitrógeno $(\mathrm{N})$ así como con bajos contenidos de $\mathrm{pH}$ y densidad aparente del suelo (DA) comparado con los $\mathrm{SGMP}(\mathrm{P} \leq 0.05)$. En ambos sistemas ganaderos, $\mathrm{MO}, \mathrm{C}$ y N del suelo fue más alto en la parte superficial $(0-10 \mathrm{~cm})$ y, en los SGCV de 3 a $6 \mathrm{~m}$ de distancia de las cercas vivas $(\mathrm{P} \leq 0.05)$. En los SGCV el pH y la DA del suelo fueron similares a diferentes profundidades y distancias de las cercas vivas $(\mathrm{P}>0.05)$. Sin embargo, $\mathrm{pH}$ del suelo varió entre las profundidades del suelo en los SGMP. En cuanto a las propiedades físicas del suelo, sólo las proporciones de arena y arcilla variaron a diferentes profundidades en ambos sistemas, pero no a diferentes distancias de los sistemas ganaderos con cercas vivas $(\mathrm{P} \leq 0.05)$. Se concluye que los SGCV tienen un enorme potencial para mejorar sustancialmente las propiedades físicas y químicas del suelo, siendo una oportunidad para frenar el deterioro de los suelos en sistemas de producción ganaderos basados en el monocultivo de pasto.

Palabras clave: Mejoramiento del suelo, sistema silvopastoril, monocultivo de pasto señal, trópico húmedo.

\section{References}

Berninger, F., and E. Salas. 2003. Biomass dynamics of Erythrina lanceolata as influenced by shootpruning intensity in Costa Rica. Agroforestry Systems 57:19-28.

Campdell, G.S., R.D. Jackson, M.M. Mortland, D.R.
Nielsen, and A.K. Chair (eds). 2010. Methods of soils analysis. Part 1-Physical and mineralogical Mtehods. Soil Science Society of America Book Series Madison, WI. 1358 pp.

Carvajal, J.J. 2005. Establecimiento de postes de Chacah (Bursera simaruba, L. Sarg.) como cerco vivo. Livestock Research for Rural De- 
velopment 17(22). Available online at: http:// www.cipav.org.co//rrd//rrd17/2/carv17022. htm (Website accessed May 25, 2006).

Carter, M.R. 2002. Soil quality for sustainable land management: organic matter and aggregation interactions that maintain soil functions. Agron. J. 94:38-47.

Dube, F., M. Espinosa, N.B. Stolpe, E. Zagal, N.V. Thevathasan, and A.M. Gordon. 2012. Productivity and carbon storage in silvopastoral systems with Pinus ponderosa and Trifolium spp., plantations and pasture on an Andisol in Patagonia, Chile. Agroforestry Systems. DOI 10.1007/ s10457-011-9471-7.

García, E. 1988. Modificaciones al sistema de clasificación de Köppen. México, D.F. 219 pp.

Graham, S., B.R. Wilson, N. Reid, and H. Jones. 2004. Scattered paddock trees, litter chemistry, and surface soil properties in pastures of the New England Tablelands, New South Wales. Australian Journal of Soil Research 42:905-912.

Grande, D., F. De León, J. Nahed, and F. Pérez-Gil. 2010. Importance and Function of Scattered Tress in In the Sierra Region of Tabasco, Mexico. Research Journal of Biological Sciences 1:75-87.

Hossne, A.J. 2008. Bulk density and its agricultural implications in the soil expansion/shrinkage process. Terra Latinoamericana, 26: 195-202

Howard, R.F., and D.M.J Singer. 1981. Measuring forest soil bulk density using irregular hole paraffin clod and air permeability. Forest Sciences 27:316-322.

INEGI - Instituto Nacional de Estadística Geografía e Informática. 2009. Censo Agropecuario 2007, VII Censo Agrícola, Ganadero y Forestal. Aguascalientes, México. Available online at: http://www.inegi.org.mx/est/contenidos/proyectos/Agro/ca2007/Resultados_ Agrícola/default. aspx (Website accessed May 19, 2011).

Klein, D., P. Fuentes, and A. Schmidt. 2008. Soil organic $\mathrm{C}$ as affected by silvicultural and explotaitive intervention in Nothofagus pumilo forests of Chilean Patagonia. Forest Ecology and Management 255:3549-3555.

La Scala, J.N., E.B. De Figueiredo, and A.R. Panosso. 2012. A review on soil carbon accumulation due to the management change of major Brazilian agricultural activities. Braz. J. Biol. 72:775-785.

Maldonado, M., D. Grande, E. Fuentes, S. Hernández, F. Pérez-Gil, and A. Gómez. 2008. Los sistemas silvopastoriles de la región tropical húmeda de México: El caso de Tabasco. Zootecnia Tropical 26:305-308.

Manning, A.D., J. Fischer, and D.B. Lindenmayer. 2006. Scattered trees are keystone structures Implications for conservation. Biological Conservation 132:311-321.

Matos, E.S., D. Freese, E.S. Mendonca, A. Slazak, and F.H. Reinhard. 2012. Carbon, nitrogen and organic $\mathrm{C}$ fractions in topsoil affected by conversion from silvopastoral to different land use systems. Agroforestry Systems 81:203-211.

McKenzie, N.J., D.J. Jacquier, R. F. Isbell, and K. L. Brown. 2004 Australian soils and landscapes an illustrated compendium. CSIRO Publishing: Collingwood, Victoria.

Martínez, H E., E.J.P. Fuentes, and H.E. Acevedo. 2008. Carbono orgánico y propiedades del suelo. Journal Soil Science Plant Nutrition 8:68-96.

Moya, R., L.V. Arce, P.E. González, G.C. Olivares, and G.V. Ríos. 2010. Efecto de las propiedades físicas y químicas del suelo en algunas propiedades de la madera de teca Tectona grandis. Revista Árvore, Viçosa-MG 34:1109-1118.

Oelbermann, M., R.P. Voroney, N.V. Thevathasan, A M. Gordon, D C.L. Kass, and A.M. Schlonvoigt. 2006. Soil carbon dynamics and residue stabilization in a Costa Rican and southern Canadian alley cropping systems. Agroforestry Systems 68:27-36.

Pajares, M.S., J.F. Gallardo, and J.D. Etchevers. 2010. Indicadores bioquímicos en suelos de un transecto altitudinal en el eje neovolcánico mexicano. Agrociencia 44:261-274.

Sánchez, V.G., J.J. Obrador, D.J. Palma, and S. Salgado. 2003. Densidad aparente en un vertisol con diferentes agrosistemas. INCI [online] 28(6):347351. Available online at: http://www.scielo.org. ve/scielo.php?script=sci_arttext\&pid=S0378$18442003000600007 \& \operatorname{lng}=$ en\&nrm=iso (Website accessed March 21, 2013.

Schmitt, H.M., T.P. Evans, E. Castellanos, and J.C. Randolph. 2012. Carbon stocks in coffee agroforests and 
mixed dry tropical forests in the western highlands of Guatemala. Agroforestry Systems 86:141-157.

Schoeneberger, M.M. 2008. Agroforestry: working trees for sequestering carbon on agricultural lands. Agroforestry Systems 75:27-37.

Soto, L., M. Anzueto, J. Mendoza, G. Jiménez, and B. De Jong. 2010. Carbon sequestration through agroforestry in indigenous communities of Chiapas, Mexico. Agroforestry Systems 78:39-51.

Sparks, D.L., A.L. Page, P.A. Helmke, R.H. Loeppert, P.N. Soltanpour, M.A. Tabatabai, C.T. Johnson, and M.E. Sumner (eds.). 2007.Methods of
Soil Analysis. Part 3 - Chemical Methods. Soil Science Society of America Book Series. Madison, WI. 1264 pp.

Tapia, C., F.J. Luizäo, E. Wandelli, and E.C.M. Fernandes. 2005. Carbon and nutrient stocks in the litter layer of agroforestry systems in central Amazonia, Brazil. Agroforestry Systems 65:33-42.

Wong, M.T.F., P. Gibbs, S. Nortcliff, and R.S. Swift. 2000. Measurement of the acid neutralizing capacity of agroforestry tree prunings added to tropical soils. Journal of Agricultural Science, Cambridge 134:269-276. 